\title{
Examining Trends of UAE's Exports - Current and Future Perspective
}

\author{
M. Hazem Shayah
}

\begin{abstract}
Over the last 30 years, the UAE has transformed into one of the most competitive countries in the world. As the UAE non-oil economy continues to develop, it is becoming an increasingly intensive consumer of energy. All of that is creating motivation for more economic diversification. In this paper I discuss the export policies of the UAE focusing on current trends of the UAE's exports, and I predict future opportunities which may expand total exports of the country.
\end{abstract}

Index Terms-Economic diversification, exports, trade, UAE.

\section{INTRODUCTION}

As member of the World Trade Organization since 1996, the UAE has effectively established itself as a prominent player in the international trading system. This is the consequence of its efforts which have been made to diversify its economy through enhancing trade relationships and exchange in non-oil products with countries all around the world, while adopting an open economy with an attractive business environment that promises continuous economic growth.

The UAE has a relatively liberal trade regime, although a number of limitations and conditions are set on foreign investment. The broad strategy set by the Ministry of Foreign Trade aims to, inter alia, promote the UAE's trade relations with its trading partners; increase the contribution of foreign trade to GDP; maintain the commercial and investment interests of the country; and increase foreign investment flows to its markets. Improved market access for its products through multilateral trade liberalization and bilateral and regional trade agreements is a main trade policy objective.

The UAE coordinates its engagement in regional agreements with its participation at the multilateral level through relevant committees, which hold regular meetings [1]. The United Arab Emirates recorded a trade surplus of 503694 AED million in 2013, (one USD is about 3.67 Emirati Dirham).

A lively non-oil sector will continue attracting FDI inflows. Because of its lower dependence on oil revenues, UAE has managed to resist the trend of declining FDI inflows to GCC. Increased infrastructure investment, growing tourism, and Expo 2020 is likely to boost foreign investor confidence

Manuscript received November 21, 2014; revised February 3, 2015.

M. Hazem Shayah is with the School of Economics, Wuhan University of Technology, Wuhan, Hubei, China (e-mail: mhsh85@ hotmail.com). further, and help FDI inflows rise above USD 10.5 bn level achieved in 2013.

\section{UAE'S EXPORT POLICY}

Export policy is a collection of rules and regulations which concern export. Every nation has some form of export policy in place, with public officials formulating the policy which they think would be most appropriate for their country. The purpose of this policy is to help a nation's international trade run more smoothly, by setting clear standards and goals which can be understood by potential trading partners. In many regions, groups of nations work together to create mutually beneficial trade policies.

As a result of the UAE's exports diversification policy, less than half of its export value directly comes from oil and gas products. A crucial factor that has contributed to such diversification is the UAE's so called "Free Trade Zones". The zones are designated areas within the UAE where traditional laws and regulations governing licensing, agency requirements, and UAE majority ownership are completely eliminated, creating dynamic business environments conducive to unhindered growth. Building upon its commitment to free international trade, the UAE has taken the initiative in engaging several countries in order to negotiate bilateral trade agreements alongside the GCC nations. These countries include the European Union (as a single trading bloc), Turkey, China, Australia, as well as the United States. Overall, the UAE's trade policy has been consistent with its obligations under the WTO. A free, competitive and open trade policy is seen as one of the main drivers behind the UAE's growth and will continue to play a significant role as the country builds on its recent achievements [2].

The UAE's average tariff rate is 3.7 percent. Non-tariff barriers are not a significant deterrent to trade. The modern financial sector is efficient and competitive. Banks offer a full range of services. Islamic banking is increasingly prominent. State-owned banks have maintained a strong presence, and foreign banks have over 100 branches around the country.

The growth rate of the UAE's non-oil foreign trade has been stable for the last ten years except in 2009 when global trade dropped by $13 \%$ as a result of economic turmoil. Nevertheless, 2010 saw a strong return when the UAE's total foreign trade increased by $14 \%$, from 179.8 billion USD in 2009 to 205.42 billion USD. The ongoing growth in foreign trade reflect the country's strong commitment, through its free trade policies, advanced logistics and encouraging innovative projects to preserve its strong standing in the global trade market.

The UAE's foreign trade volume increased from 2005 until 
2010 with an average growth rate of $19 \%$ as a result of an increase in exports (non-oil exports and re-exports). The share of total exports (non-oil exports + re-exports) amounted to $35.7 \%$ of the country's total foreign trade in 2010 [3].

The drivers of economic growth in the UAE are vulnerable to external shocks outside of the Emirate's control. Greater efforts are needed to stimulate the diversification of the production base by encouraging increased domestic, especially private, investment. Well-targeted policies should be adopted to accelerate reform and facilitate the involvement of the private sector in the economy [4]

\section{A. Major UAE's Commodities Exported}

The UAE, the country with the most diversified economy in the region, has significantly developed tourism, finance and transport industries. Especially the tourism sector has become one of the main sectors of the UAE economy in terms of revenue generating [5] anyway, the UAE economy is still largely depending on oil exports out of Abu Dhabi. Because the UAE is one of the 10 largest producers of oil and natural gas in the world with large proven oil reserves ( 98 bn barrels).
In 2012, it benefitted from high oil prices, which helped bring more revenues for the government. Abu Dhabi has the largest share and controls $94 \%$ of the UAE's overall oil production capacity of 2.7 million barrels per day (mbpd); Dubai's reserves are about $(4.1 \%)$ and as a result, its government has attempted to find an aggressive diversification policy, with a vision to make it the Middle East's business, trade, media and tourism hub.

In addition to oil, there are many commodities exported by UAE and classified as follows in (Table I).

TABLE I: MAJOR UAE'S COMMODITIES EXPORTED

\begin{tabular}{|c|c|}
\hline Precious metals \& stones & Plastics \\
\hline Aluminum & paper \\
\hline processed food & furniture \\
\hline Iron \& Steel & electrical machinery \\
\hline Minerals fuels \&oils & Ceramic \\
\hline
\end{tabular}

From 2009 to 2011, the largest export commodity was "petroleum oils, crude" (HS code 2709) as we can see in (Table II) according to Standard International Trade Classification [6].

TABLE II: TOP 10 EXPORT COMMODITIES 2009 TO 2011

\begin{tabular}{|c|c|c|c|c|c|}
\hline \multirow[t]{2}{*}{ HS code } & \multirow{2}{*}{ 4-digit heading of Harmonized System 2002} & \multicolumn{3}{|c|}{ Value (million US\$) } & \multirow[t]{2}{*}{ SITC code } \\
\hline & & 2009 & 2010 & 2011 & \\
\hline & All Commodities & 174725.0 & 198362.0 & 252556.0 & \\
\hline 2709 & Petroleum oils, crude & 43535.4 & 65482.1 & 91935.8 & 333 \\
\hline 9999 & Commodities not specified according to kind & 53154.1 & 51994.9 & 60902.6 & 931 \\
\hline 7108 & Gold (including gold plated with platinum) & 10520.8 & 11508.4 & 18201.4 & 971 \\
\hline 7102 & Diamonds, whether or not worked, but not mounted or set & 7692.7 & 15193.9 & 17087.8 & 667 \\
\hline 2710 & Petroleum oils, other than crude & 15852.0 & 6514.1 & 10087.3 & 334 \\
\hline 7113 & Articles of jewellery and parts of precious metal & 3046.3 & 3689.2 & 5458.6 & 897 \\
\hline 8703 & Motor cars and other motor vehicles principally designed for the transport & 3283.5 & 3237.1 & 3467.9 & 781 \\
\hline 2711 & Petroleum gases and other gaseous hydrocarbons & 5157.5 & 2030.7 & 2519.9 & 343 \\
\hline 8517 & Electrical apparatus for line telephony or line telegraphy & 1791.7 & 2352.2 & 2840.7 & 764 \\
\hline 8803 & Parts of goods of heading 88.01 or 88.02 & 1268.2 & 1732.5 & 1111.2 & 792 \\
\hline
\end{tabular}

\section{B. Major UAE's Exports Partners}

Merchandise exports in the United Arab Emirates were moderately concentrated amongst partners. As we can see in (Table III), which contains Goods Exports (FOB), by last known destination, Japan and India are on the top of the UAE's largest trade partners.

TABLE III: MAJOR UAE'S EXPORTS PARTNERS (2012)

\begin{tabular}{|l|l|l|l|l|l|}
\hline Japan & India & Iran & Thailand & Singapore & South Korea \\
\hline $15.4 \%$ & $13.4 \%$ & $10.7 \%$ & $5.5 \%$ & $5.5 \%$ & $5.3 \%$ \\
\hline
\end{tabular}

\section{TREND OF TOTAL EXPORTS IN UAE}

There are so many factors play a role in promoting the UAE exports, first of all that the UAE does not apply export taxes, charges, and levies, other than a tax on steel scrap exports. Exports of dual-use goods require a license. The UAE applies a number of programs to promote exports, including a Free Trade Zones (FTZ) program. Foreign ownership in firms established in FTZs may be up to $100 \%$ and investors are exempt from paying personal income taxes and corporate taxes for 15 years, renewable for an additional 15 years. Additionally, goods may be imported into a FTZ duty free. Companies located in the FTZs are exempted from agency/distributorship, sponsorship, and national ownership requirements. FTZs produce both goods and provide services [1]. In 2011, the value of merchandise exports of the United Arab Emirates increased substantially by 27.3 percent to reach 252.6 bln US\$, while its merchandise imports increased substantially by 16.7 percent to reach 210.9 bln US\$, and the merchandise trade balance recorded a relatively small surplus of 41.6 bln US\$, as we can see in (Fig. 1).

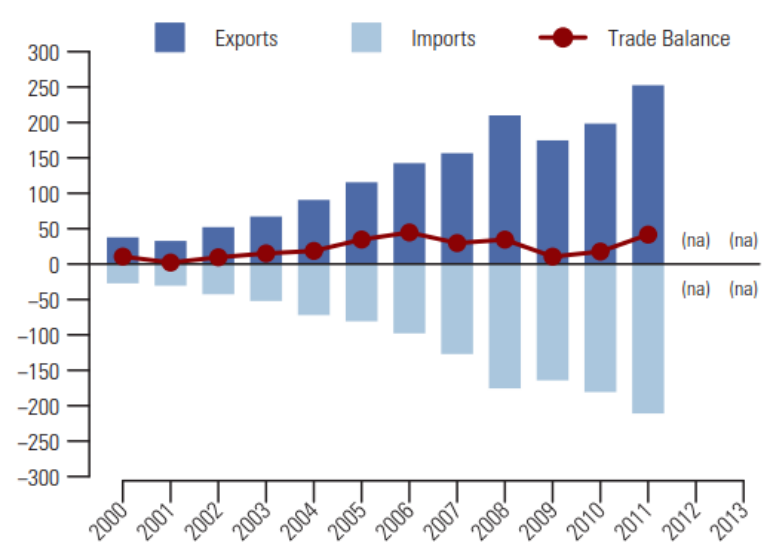

Fig. 1. Total merchandise trade, by value (billion US $\$$ by year).

While in other available data released by the UAE authorities and World Trade Report 2014 by the WTO [7], we 
can see that UAE's Exports around \$350.1 billion (2012 est.) and, $\$ 368.9$ billion (2013 est.) what make the UAE ranked 18 globally as a leading exporter country.

In a new report [8] released by International monetary fund in 2014, they make a prediction of UAE's real GDP annual percent change in these years (2014.2015.2019), as we can see in Table V, that the GDP growth will increase but in very slow rate. Recently, the oil price has fallen by more than $55 \%$ since June, 2014, when it was $\$ 115$ a barrel. It is now around $\$ 50$, this great fall in oil prices, because the global demand is low as a result of the weak economic activity. In addition, to the increased efficiency in oil extraction and the growing switch away from oil to other kinds of fuels. These dramatic changes in the global oil prices will affect the development plans, and fiscal budgets in the all GCC countries including the UAE.

\begin{tabular}{|c|c|c|c|c|c|c|c|c|c|c|}
\hline & & & & & & & & \multicolumn{3}{|c|}{ Projections } \\
\hline 2006 & 2007 & 2008 & 2009 & 2010 & 2011 & 2012 & 2013 & 2014 & 2015 & 2019 \\
\hline 16.3 & 6.9 & 7.1 & 3.1 & 2.5 & 14.7 & 18.5 & 16.1 & 11.1 & 11.8 & 5.7 \\
\hline
\end{tabular}

TABLE V: UAE's REAL GDP (ANNUAL PERCENT CHANGE)

\begin{tabular}{|c|c|c|c|c|c|c|c|c|c|c|c|}
\hline Average & & & & & & & \multicolumn{4}{|c|}{ Projections } & \multicolumn{3}{|c|}{} \\
\hline $1996-2005$ & 2006 & 2007 & 2008 & 2009 & 2010 & 2011 & 2012 & 2013 & 2014 & 2015 & 2019 \\
\hline 5.8 & 9.8 & 3.2 & 3.2 & -5.2 & 1.6 & 4.9 & 4.7 & 5.2 & 4.3 & 4.5 & 4.6 \\
\hline
\end{tabular}

\begin{tabular}{|c|c|c|c|c|c|c|c|}
\hline & 2010 & 2011 & 2012 & 2013E & $2014 E$ & 2015E & 2016E \\
\hline Trade Balance (USD Bn) & 46.3 & 102.3 & 124.2 & 120.1 & 122.6 & 120.3 & 119.1 \\
\hline Oil \& Gas Exports & 74.7 & 111.6 & 118.1 & 115.5 & 116 & 112.8 & 110.6 \\
\hline Non-Oil Exports & 51 & 70.9 & 96.3 & 108.9 & 120.3 & 134.2 & 150.5 \\
\hline Re-Exports & 86.2 & 116.7 & 132.6 & 142.5 & 156.3 & 172.6 & 191.6 \\
\hline Imports & 165.6 & 196.3 & 222.8 & 246.8 & 270 & 299.3 & 333.6 \\
\hline $\begin{array}{c}\text { Net Services, Income, Transfers (USD } \\
\text { Bn) }\end{array}$ & 41.4 & 4.8 & 60.8 & 64.1 & 67.4 & 71.4 & 74.1 \\
\hline Current Account Balance (USD Bn) & 4.9 & 48.1 & 63.4 & 56 & 55.2 & 48.9 & 45 \\
\hline
\end{tabular}

Source: KAMKO Research, (2014)

The global crisis has severely hit the UAE economy, so we can see that in 2009 the UAE's Real GDP (Annual percent change) was -5.2 , led by a remarkable fall in manufacturing, in addition to the real estate sector. In 2009, the crisis hit more heavily the whole economy than the non oil sector. However, the economy regained confidence after the crisis. We have seen a growing legal and financial maturity developing alongside UAE's economic recovery, bringing it closer in line with other longer established business centers of the world.

In 2010 the growth of GDP was a respectable 1.6 annual percent change as illustrated in (Table V).

\section{UAE BALANCE OF PAYMENT}

The surplus in the trade balance (FOB) increased from AED 484.7 billion in 2012 to AED 503.7 billion in 2013, due to an increase in exports of the hydrocarbon sector by AED 11.0 billion, from AED 440.6 billion to AED 451.6 billion, an increase in non-hydrocarbon exports by AED 42.2 billion, from AED 354.2 billion to AED 396.4 billion, and an increase in re-exports by AED 53.9 billion, from AED 488.7 billion in 2012 to AED 542.6 billion in 2013. Meanwhile, total imports (FOB) increased by AED 88.2 billion.

In the recent years there is an increase in the total exports of UAE, in addition to investments and inflow of capital inside the country. As a result of these developments, the overall position of the balance of payments remained in surplus, reaching AED 77.3 billion in 2013 [9], while the surplus was nearly Dh36.6 billion in 2012 compared with Dh16.2 billion in 2011 .

Non-oil exports are projected to increase $56 \%$, from USD $96.3 \mathrm{Bn}$ in 2012 to USD $150.5 \mathrm{Bn}$ in 2016 , on the back of healthy demand from Asia, UAE's main destination for goods trade. Decline in oil exports might be arrested as oil prices recover. Overall, current account will remain healthy and in surplus (>10\% of the GDP) [10].

\section{UAE'S EXPORTS A FUTURE PERSPECTIVE}

UAE real GDP growth was 5.2 in 2013 while is predicted to be $4.7 \%$ in 2014 and $4.5 \%$ in 2015 according to the World Bank [11]. Trade reform alone will not by itself be adequate to deliver large supply responses in terms of increasing trade volumes, expanding export varieties, and attracting FDI inflows, as other considerations including lack of sufficient infrastructure can prevent local or foreigner producers from increasing production of raw materials for export, and the lack of an enabling environment can hinder entrepreneurship and innovation. So the big challenge for the UAE is maintaining the edge as a global international hub for aviation, business, tourism, and trade by building more sufficient infrastructure and create helpful environment for business and trade.

By the meanwhile growth in oil production likely will slow down in spite of weak oil prices and the instability in the Middle East. A flexible combination of state intervention, market forces, open trade and micro and macro-policies, and 
public and private partnerships can play a key role in the improvement of UAE' export competitiveness and integration of the country industry and SMEs into global supply chains.

Regarding the merchandise exports we can see that strong external demand from Asia has helped limit the impact on the UAE of the weaknesses of European economies, as a result, the emerging Asia, especially India, accounts for a large and growing share of exports. I think this will continue in the future, so in general, non-oil growth is expected to strengthen further in coming years.

The UAE should have new companies those are radical innovators able of integrating heterogeneous technologies and using the best scientific and technological research, in addition to produce and export different kinds of products and not just rely on the oil sector. I think UAE will continue the success in its established sectors: chemicals, agribusiness and food processing, one important factor played a role in this success it was the free zones because the UAE's free zones have been one of the strongest pillars of the country's economic performance, the combined output of the country's free zones accounts for more than half of its non-oil exports and underpin the UAE's ranking as the third most important re-export center in the world.

The UAE's economic growth is expected to moderate in 2015 on lower oil prices. The drop in oil prices would have limited risks to the UAE's investment plans. The main projects, which remain very important for the UAE development objectives, aim to meet recent economic requirements or increase the economic base, as well as further diversification.

The UAE have a potential for stronger growth after 2016 because of the pace of investment rising as Dubai gets closer to Expo 2020; the output capacity of the economy growing and the expected strengthening of the global outlook.

Economic growth in the coming years will remain slow in developed markets. Especially the Euro zone will only experience limited growth as the region continues to struggle with the Euro crisis. the UAE can adopt Export Oriented Industrialization strategies targeting larger markets, which is facilitated through preferential trade agreements given the size of the UAE market especially with some countries in the EU and the Asian countries because the World output growth is strongly driven by emerging markets, in particular China and other developing Asian countries, so I think UAE can gain profits by boosting exports to these countries especially (China, Japan, Iran, and India).

Lastly, this research raises some questions which would benefit from further future research. First, what are the alternative pathways for the UAE economy?

The answer to this question may give us new ways regarding the development and economic diversification in the GCC countries after the recent volatility in the global oil prices. Second, what are the measures which the UAE may adopt to help firms improve their export competitiveness, and by solving coordination failures and providing efficient services.

\section{CONCLUSIONS}

The UAE has made great investments to establish itself as a regional business, and trade hub. While the physical infrastructure has been upgraded, further progress is needed in the area of trade facilitation. The UAE's exports diversification policy is promising, and as a result of that policy, now less than half of its export value directly comes from oil and gas products, while the merchandise exports in the United Arab Emirates still moderately concentrated amongst partners.

The UAE's good economic performance and the stable condition of the different economic sectors will contribute to reinforcing the attractiveness of the UAE as a safe place for investors looking to diversify their investments from unstable traditional markets. So the UAE's goal should be to keep this status, and build a robust, effective exporting system with the emerging markets in Asia away from the different economic crisis in other parts of the world.

\section{REFERENCES}

[1] World Trade Organization, Trade Policy Review Report by United Arab Emirates, (WT/TPR/G/262), February 21, 2012.

[2] UAE Trade Policy. [Online]. Available: http://www.uaetrade-usa.org/index.php?page=uae-us-relations\&cmsi $\mathrm{d}=64$

[3] M. H. Shayah and Y. Qifeng, "Development of free zones in United Arab Emirates," presented at the First Middle East Conference on Global Business, Economics, Finance and Banking, Dubai, October $10-12,2014$

[4] I. Haouas and A. Heshmati, "Can the UAE avoid the oil curse by economic diversification?” IZA Discussion Paper, no. 8003, 2014.

[5] A. Insel and M. M. Tekçe, "Modelling the trade flows of the gulf cooperation council countries: A new approach to gravity model," Discussion Paper, Turkish Economic Association, no. 2010/2, 2009.

[6] UN Comtrade and UN Servicetrade. [Online]. Available: http://comtrade.un.org/db/

[7] World Trade Organization, World Trade Report 2014, 2014.

[8] International Monetary Fund, World Economic Outlook, October 2014.

[9] Central Bank of the United Arab Emirates, Annual Report, 2013.

[10] KAMCO Investment Research, "GCC economic report," Kamco Research Report, August 2014

[11] World Bank, MENA Economic Monitor, October 2014.

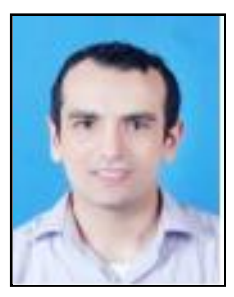

M. Hazem Shayah received the bachelor degree in business administration from University of Aleppo, Aleppo, Syria in 2007, and the master degree in international trade from Wuhan University of Technology, Wuhan, China in 2012. Currently he is a Ph.D. candidate in School of Economics at Wuhan University of Technology. His current research interests include trade liberalization, export growth, emerging economies and economic development. 